\title{
Religious Orientation and Psychological Distress among Parents of
}

\section{Mentally Retarded Children}

\author{
Muzafar Hussain Kawa ${ }^{1}$, Humera Shafi ${ }^{2}$
}

\section{ABSTRACT:}

The present study was an attempt to assess religious orientation and psychological distress as well as to find out relationship of religious orientation with psychological distress among parents of mentally retarded children. Parents of mentally retarded children were also compared on religious orientation and psychological distress with respect to their gender. The data for the present study was obtained from parents of mentally retarded children $[\mathrm{N}=200$ (Fathers 90 \& Mothers 110)] belonging to various districts of Kashmir valley. The data collected was analyzed by using appropriate statistical techniques like Pearson's product moment correlation and t-test. The results showed significant negative correlation between intrinsic religious orientation and psychological distress. Moreover, a significant positive correlation was found between extrinsic religious orientation and psychological distress. Significant difference was also found among parents of mentally retarded children on intrinsic religious orientation and psychological distress with respect to their gender. However, no significant difference was found among parents of mentally retarded children on extrinsic religious orientation with respect to their gender.

Keywords: Mental retardation, Religious Orientation, Psychological Distress

\section{INTRODUCTION:}

Mental Retardation or Intellectual disability (intellectual developmental disorder) is a disorder with onset during the developmental period that includes both intellectual and adaptive functioning deficits in conceptual, social, and practical domains. The following three criteria must be met:

A. Deficits in intellectual functions, such as reasoning, problem solving, planning, abstract thinking, judgment, academic learning, and learning from experience, confirmed by both clinical assessment and individualized, standardized intelligence testing.

\footnotetext{
${ }^{1}$ Research Scholar, Department of Psychology, University of Kashmir, J\&K, India

${ }^{2}$ Sr. Assistant Professor, Department of Psychology, University of Kashmir, J\&K, India
} 


\section{Religious Orientation and Psychological Distress among Parents of Mentally Retarded Children}

B. Deficits in adaptive functioning that result in failure to meet developmental and sociocultural standards for personal independence and social responsibility. Without ongoing support, the adaptive deficits limit functioning in one or more activities of daily life, such as communication, social participation, and independent living, across multiple environments such as home, school, work, and community.

C. Onset of intellectual and adaptive deficits during the developmental period. (Diagnostic and statistical Manual of mental disorders [DSM-5], 2013).

According to the World Health Organization (WHO), 10\% of the world's population has some form of mental disability and $1 \%$ suffers from severe incapacitating mental disorders (WHO, 1989). Prevalence of mental retardation is 3\% all over the world. However $75 \%$ of them fall into mild mental retardation category, while the rest $25 \%$ having IQ (Intelligence Quotient) of below 50 are classified as moderately, severely or profoundly retarded (ICD 10). The National Sample Survey Organization report estimates the prevalence of mental disabilities in India to as little as $0.2 \%$ (NSSO, 2003).

India is the second most populous country of the world with 1.21 billion populations (census, 2011). The 2011 census in India which has included the disability count as an ingredient in the National Agenda reported that a total of 26,810,557 persons are disabled and the prevalence rate of disability is 2.21 per cent of the general population in India. The total number of mentally retarded persons in India is 1,505,624 and among them 1,85,070 are children (Census, 2011). The prevalence rate of mental retardation in general population in India is 0.124 percent. Among the eight types of disabilities on which data has been collected, disability in mental retardation is $5.6 \%$ (Census, 2011). The total population of disabled persons in $\mathrm{J} \& \mathrm{~K}$ state as per census, 2011, is 3,61, 153. Out of total disabled, 16,724 are mentally retarded. Individuals have been categorized as mentally retarded constitutes 4.63 percent of the disabled in J\&K (Census, 2011).

\section{Religious Orientation}

Religious orientation differs from religious affiliation, which refers to theological categories of, for example, Catholic, Protestant, Pentecostal, Jewish, Orthodox, Reformed, Conservative, Fundamentalist or Liberal (Levin \& Schiller, 1987). The psychology of religion has examined the issue of how individuals approach religion for some time, especially since the work of Allport and Ross (1967) helped to conceptualize two religious orientations: intrinsic and extrinsic. The essential distinction between the two orientations lies in the way individuals approach religion and in what light they view their religiosity. The extrinsic orientation describes a pattern of religious involvement marked by an individual's interest in gaining something from religious participation. Religion thus becomes a tool for the achievement of goals, such as social contact or the improvement of one's financial situation. Further, the values of a faith may be utilized for specific purposes, such as the promotion of an individual's own beliefs or worldview through the strengthened religious justification. 


\section{Religious Orientation and Psychological Distress among Parents of Mentally Retarded Children}

The intrinsic religious orientation is linked to seeing religion as an end in and of itself. Individuals who score high on this religious orientation tend to shape their other life events around their religiosity. These individuals are comfortable with their beliefs and are not motivated to bend their religion to fit or justify their actions; instead, they model their actions on religious doctrines and teachings. In other words, "the extrinsically motivated individual uses his religion and the intrinsically motivated lives his religion," (Allport \& Ross, 1967).

The birth of a disabled child is an event that affects all the family members. It requires a reassessment of the family functioning (Cohen, Friedrich, \& Jaworski, 1994; Dyson 1989; Gallimore, Weisner, Kaufman, \& Bernheimer, 1989; Heaman, 1995). The majority of families cope with the situation relatively well and are able to continue their life normally (Flynt, Wood, \& Scott, 1992; Gibson 1995; Hamlett, Pellegrini, \& Katz, 1992).However, coping with a physically or intellectually disabled child is a highly individual process, and there is evidence to suggest that some families may never adjust fully to this event (Gibson, 1995; Koller, Richardson, \& Katz, 1992). A number of studies have consistently demonstrated that religious beliefs and practices are related to greater life satisfaction, happiness, positive affect, morale, and other indicators of wellbeing (Koenig, McCullough, \& Larson, 2001). In an investigation of the relationship between religious rituals and mental health, it has been found that cross-culturally, religious ceremonies play a significant role in reducing anxiety and isolation as emotions are acknowledged, expressed, and resolved within a social milieu of attachment and connection to significant others (Shumaker, 1992). Religion has also been found to act as a resource for fathers coping with their special needs children, as a father's experience revolves around his religious beliefs and practices and his relational resources (Olson, Dollahite, \& White, 2002).

\section{Psychological Distress}

Psychological distress is widely used as an indicator of the mental health of the population in public health and in population surveys. Psychological distress is viewed as an emotional condition that involves negative views of the self, others and the environment and is characterised by unpleasant subjective states such as feeling tense, worried, worthless and irritable (Barlow \& Durand, 2005).

The burden of raising a mentally retarded child tends to lead their parents to psychological distress. The demands of caring for children with chronic conditions may precipitate symptoms of depression and general psychological distress (Breslau \& Davis, 1986; Jessop, Riessman \& Stein, 1988). In addition, both the general psychological literature and specific studies of disabled children show that parental distress and family functioning impacts children in numerous ways, affecting their cognitive, behavioural and social development. Parental psychological distress contributes significantly to behavioural and emotional problems among chronically ill children (Thompson, Gil, Burbach, Keith, \& Kinney, 1993).

Recently, the idea of a "religion-health connection" has gained traction among clinicians. Literature reviews and academic and popular books have focused attention on social, behavioural, epidemiologic, and clinical research papers that total in the thousands (Koenig, 
McCullough \& Larson, 2001; Levin \& Chatters, 1998; Levin, 2001). These studies explore the impact of religious indicators on psychiatric and mental health outcomes in population, community, and hospital samples: rates of mood disorders, such as depression and anxiety; levels of psychological distress, using numerous assessment instruments; dimensions of psychological well-being, such as life satisfaction and happiness; patterns of self-destructive behaviour, including the addictions; and mental health care utilization. The weight of evidence, on average and across studies, suggests that religion, however assessed, is a generally protective factor for mental illness. Medical sociologists, health psychologists, and gerontologists have done a more sophisticated job at identifying impacts of religious life on mental health indicators. Studies of dimensions of psychological distress and well-being, many of them large-scale probability surveys, consistently find a protective effect of religious participation (Levin \& Chatters, 1998).

\section{OBJECTIVES}

1. To study religious orientation, psychological distress and frustration among the parents of mentally retarded children.

2. To study the relationship between religious orientation and psychological distress among the parents of mentally retarded children.

3. To study the significance of difference of religious orientation and psychological distress on the basis of gender among the parents of mentally retarded children.

\section{HYPOTHESES}

Ho: : There is no significant relationship between intrinsic religious orientation and Psychological distress among the parents of mentally retarded children.

$\mathrm{Ho}_{2}$ : There is no significant relationship between extrinsic religious orientation and Psychological distress among the parents of mentally retarded children.

Ho3: There is no significant difference in intrinsic religious orientation among the parents of mentally retarded children with respect to their gender.

Ho4: There is no significant difference in extrinsic religious orientation among the parents of mentally retarded children with respect to their gender.

Ho5: There is no significant difference in psychological distress among the parents of mentally retarded children with respect to their gender.

\section{METHODOLOGY}

\section{Sample}

The sample of the present study consisted of 200 parents (90 fathers and 110 mothers) of mentally retarded children. The researcher approached different institutions (Chottay Taray Foundation, Rajbagh, Srinagar; Composite Regional Centre, Bemina, Srinagar and Voluntary Medicare Society, Bemina, Srinagar) working for the welfare of mentally retarded children. These institutions provided the statistics of mentally retarded children admitted in their respective institutions along with address and contact numbers of their parents. Later on the 
researcher used purposive sampling and communicated with the parents of these mentally retarded children and sought the consent from them for participation in the present study.

\section{Tools Used}

\section{Religious Orientation Scale (1983)}

The Religious orientation was developed by Gorsuch \& Vanable, 1983. Otherwise known as Age Universal Scale of Religious Orientation, this scale contains 20 items, 8 of which are meant to characterize a person as intrinsic $(5,6,7,9,11,12,16,19)$ and rest of the 12 items $(1$, $2,3,4,8,10,13,14,15,17,18,20)$ are meant for measuring the extrinsic orientation. The Age Universal Religious Orientation Scale has internal reliability coefficients of .66 (for the extrinsic scale) and .73 (for the intrinsic scale).

Kessler Psychological Distress Scale (K10) 1996

The Kessler psychological distress scale (K10) (Kessler, 1996) is a widely used, simple self-report measure of psychological distress which can be used to identify those in need of further assessment for anxiety and depression. Kessler and colleagues (2002), found that the Cronbach's alpha for the K10 (a measure of internal consistency reliability) to be high (.93). The brief questionnaire has been shown to have good construct and criterion validity (Kessler et al., 2002), being significantly associated with measures of mental health symptoms and disability as well as the frequency on consultations for a mental health problem in the previous 12 month period.

\section{Procedure for Data Collection}

In the present study purposive sampling method was used. The parents were approached personally in their homes after taking the information regarding those parents from the institutions (Chottay Taray Foundation, Rajbagh, Srinagar; Composite Regional Centre, Bemina, Srinagar and Voluntary Medicare Society, Bemina, Srinagar) working for the welfare of these children. Informed consent was taken from parents in order to seek their voluntary participation and only those parents were included who agreed to take part in this study.

\section{Analysis}

The information/responses collected from the respondents were subjected to various statistical treatments. The data was analysed by using Statistical Product and Service Solutions (SPSS 16.0). Statistical techniques used for analyzing data were: frequencies, percentages, correlation and t-test. 


\section{RESULTS AND DISCUSSION:}

\section{Table 1}

Showing Frequency and Percentage of Sample Group With Respect to Intrinsic Religious Orientation

\begin{tabular}{|l|c|c|c|}
\hline Level & Range & $f$ & $\%$ \\
\hline Low & $8-12$ & 12 & 6 \\
\hline Moderate & $13-20$ & 111 & 55.5 \\
\hline High & $21-24$ & 77 & 38.5 \\
\hline Total & & 200 & 100 \\
\hline
\end{tabular}

Table 1 reveals that out of 200 parents of mentally retarded children $6 \%$ were found low on intrinsic religious orientation, $55.5 \%$ show moderate level of intrinsic religious orientation and $38.5 \%$ of parents were found high on intrinsic religious orientation. These results have also been presented diagrammatically in Fig. 1 on page no. 8.

Table 2

Showing Frequency and Percentage of Sample Group With Respect to Extrinsic Religious Orientation.

\begin{tabular}{|l|c|c|c|}
\hline Level & Range & $f$ & $\%$ \\
\hline Low & $12-18$ & 5 & 2.5 \\
\hline Moderate & $19-30$ & 140 & 70 \\
\hline High & $31-36$ & 55 & 27.5 \\
\hline Total & & 200 & 100 \\
\hline
\end{tabular}

Table 2 reveals that out of 200 parents of mentally retarded children, $2.5 \%$ were found low on extrinsic religious orientation, $70 \%$ show moderate level of extrinsic religious orientation and $27.5 \%$ of parents were found high on extrinsic religious orientation. These results have also been presented diagrammatically Fig. 2 on page no. 8 .

Table 3

Showing Frequency and Percentage of Sample Group With Respect to Psychological Distress.

\begin{tabular}{|l|c|c|c|}
\hline Level & Range & $f$ & $\%$ \\
\hline Low & $10-20$ & 87 & 43.5 \\
\hline Moderate & $21-30$ & 72 & 36 \\
\hline High & $31-50$ & 41 & 20.5 \\
\hline Total & & 200 & 100 \\
\hline
\end{tabular}

Table 3 reveals that out of 200 parents of mentally retarded children, $43.5 \%$ of were found low on psychological distress, where as $36 \%$ were moderate and $20.5 \%$ were high on psychological distress. These results have been presented diagrammatically on page no. 9 . 
Religious Orientation and Psychological Distress among Parents of Mentally Retarded Children

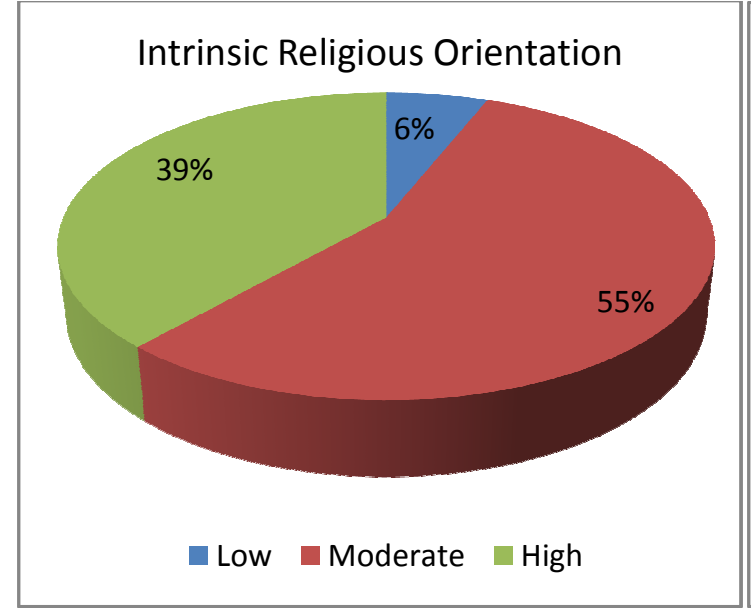

Fig. 1

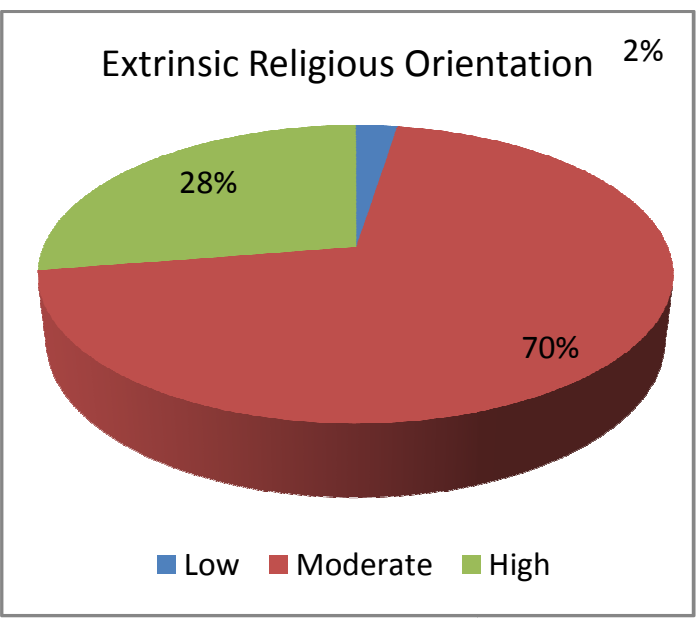

Fig. 2

Figure 1 and 2 shows percentage of sample group in three levels with respect to intrinsic religious orientation and extrinsic religious orientation.

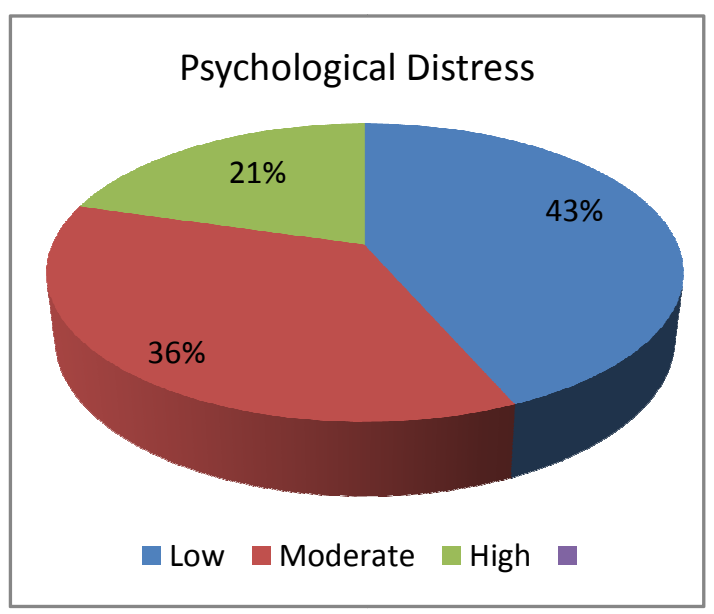

Figure 3 shows percentage of sample group in three levels with respect to psychological distress.

Table 4

Showing Pearson's Correlation Coefficient(r) Between Religious Orientation and Psychological Distress of the Sample Group

\begin{tabular}{|l|c|}
\hline Variable & $r$ \\
\hline Intrinsic Religious Orientation & $-.643 *(\mathrm{p}=<0.001)$ \\
\hline Psychological Distress & $.815^{*}(\mathrm{p}=<0.001)$ \\
\hline Extrinsic Religious Orientation & \\
\hline Psychological Distress & \\
\hline
\end{tabular}

*.P $\leq 0.05$ Level of significance

Table 4 reveals that there is a significant negative correlation $(\mathrm{r}=-.643, \mathrm{p}=<0.001)$ between intrinsic religious orientation and psychological distress among parents of mentally retarded children, indicating "more the intrinsic religious orientation, less is the psychological 
distress and vice-versa."Thus our null hypothesis $\mathrm{Ho}_{1}$ which states that, "There is no significant relationship between intrinsic religious orientation and psychological distress among the parents of mentally retarded children" stands rejected.

The table further reveals that there is a significant positive correlation between extrinsic religious orientation and psychological distress $(\mathrm{r}=.815, \mathrm{p}=<0.001)$ among parents of mentally retarded children indicating that "more the extrinsic religious orientation, more is the psychological distress and less the extrinsic religious orientation, less is the psychological distress." Thus, our null hypothesis $\mathrm{Ho}_{2}$ which states that, "There is no significant relationship between extrinsic religious orientation and psychological distress among the parents of mentally retarded children" stands rejected.

Table 5

Showing Comparison of Mean Scores of Intrinsic Religious Orientation, Extrinsic Religious Orientation and Psychological Distress among Parents of Mentally Retarded Children With Respect to their Gender

\begin{tabular}{|l|l|c|c|c|c|c|}
\hline Variable & Gender & $n$ & $M$ & $S D$ & $d f$ & t-value \\
\hline Intrinsic Religious & Mothers & 110 & 17.20 & 4.04 & & \\
\hline Orientation & & & & & 198 & $5.69^{*}$ \\
\hline & Fathers & 90 & 20.17 & 3.18 & & \\
\hline Extrinsic Religious & Mothers & 110 & 27.76 & 4.35 & & \\
\hline Orientation & & & & & 198 & $1.20^{\mathrm{NS}}$ \\
\hline Psychological & Fathers & 90 & 26.96 & 4.97 & & \\
\hline Distress & Mothers & 110 & 25.94 & 6.65 & & \\
\hline & & & & & 198 & $10.40^{*}$ \\
\hline Total N=200 & Fathers & 90 & 17.22 & 4.81 & & \\
\hline
\end{tabular}

$\mathrm{NS}=$ insignificant, $* . \mathrm{P} \leq 0.05$ Level of significance

Table 5 reveals that there is a significant difference in intrinsic religious orientation and psychological distress between mothers and fathers of mentally retarded children $(t=5.69$, $\mathrm{p}=.001 \& \mathrm{t}=10.40, \mathrm{p}=0.001)$. The results show that mothers have more psychological distress and fathers are high in intrinsic religious orientation. Thus, our null hypotheses $\mathrm{Ho}_{3}$, which states that "There is no significant difference in intrinsic religious orientation among the parents of mentally retarded children with respect to their gender"; and $\mathrm{Ho}_{5}$, "There is no significant difference in psychological distress among the parents of mentally retarded children with respect to their gender" stands rejected.

The above table further reveals that there no significant difference in extrinsic religious orientation between mothers and fathers of mentally retarded children $(t=1.20, p=.229)$. Therefore, the hypothesis $\mathrm{Ho}_{4}$, which states that "There is no significant difference in extrinsic 
Religious Orientation and Psychological Distress among Parents of Mentally Retarded Children

religious orientation among the parents of mentally retarded children with respect to their gender", stands accepted.

\section{DISCUSSION}

The aim of the present study was to study the religious orientation and psychological distress among the parents of mentally retarded children and relation of religious orientation with psychological distress. The comparison among parents of mentally retarded children on religious orientation and psychological distress with respect to their gender has also been examined.

The results of the present study revealed that there is a significant negative correlation between intrinsic religious orientation and psychological distress among parents of mentally retarded children. There are several studies which are in line with the these results. Research studies have shown that intrinsic religious orientation has inverse association with psychological distress, maladjustment, anxiety and depression (Genia, 1996; Hackey, \& Sanders, 1996; Ventis, 1995). Moreover, several researchers have found that intrinsic religious orientation serves as a buffer and is negatively correlated to a depressive reaction to negative life events (Hettler, \& Cohen, 1998; Kendler, Gardner, \& Prescott, 1997; Park, Cohen, \& Herb, 1990). An intrinsic orientation to religion is found to share a significant negative association with depressive symptoms (Genia, 1996; Genia \& Shaw, 1991; Koenig, 1995). Similarly, Maltby and Day (1999) investigated the relationship between religious orientation and depression and found that depressive symptoms are associated with lower measures of intrinsic religious orientation, optimism, self-esteem and problem-focused coping. Studies conducted by Skinner, Correa, Skinner, \& Bailey, (2001) and Biesinger, \& Arikawa (2008), revealed that intrinsic religious orientation was associated with greater level of happiness and lower levels of depression, anxiety and stress regardless of gender. Similarly Bergin, Masters, \& Richards, (1987) in a study examined the relationship between intrinsic religious orientation and mental health and found that intrinsic religious orientation was negatively correlated with unhealthy attributes, such as anxiety, depression and irrational beliefs.

The results of the present study showed that there is a significant positive correlation between extrinsic religious orientation and psychological distress among parents of mentally retarded children. Research studies have shown that extrinsic religious orientation has clear association with psychological distress; more extrinsic religious oriented individuals, more likely report higher levels of depression and anxiety (Davis, Kerr, \& Kurpius, 2003; Park, Cohen, \& Herb, 1990). Those higher in extrinsic religious orientation are more likely to share a significant association with depressive symptoms (Baker \& Gorsuch, 1982; Bergin, Masters, and Richards, 1987; Genia \& Shaw, 1991; Park, Cohen \& Herb, 1990). Similarly, Maltby and Day (1999) in a study examined that among men and women, higher scores on the Beck Depression Inventory were accompanied by significantly higher scores on an extrinsic-social and extrinsic personal orientation towards religion, neuroticism, anxiety, internal, global and stable attributions, avoidance and wishful coping measures; and with significantly lower scores on intrinsic orientation towards religion, self-esteem, optimism, problem-focused and support-seeking coping style measures. A study conducted by Biesinger and Arikawa (2002) to investigate 


\section{Religious Orientation and Psychological Distress among Parents of Mentally Retarded Children}

relationship between religious attitude and happiness shows that for both fathers and mothers, being motivated by intrinsic religious beliefs was associated with greater levels of happiness. Fathers who reported having an extrinsic religious orientation were less happy and more distressed. Ghorbani and Watson (2006) in a study examined the relationship of religious orientation with alexithymia, emotional intelligence, self-consciousness, and found that higher levels of an intrinsic religious orientation were associated with higher levels of private selfconsciousness and lower levels of depression, anxiety, and perceived stress. On the other hand, higher levels of an extrinsic religious orientation were related to difficulty identifying and describing feelings and with more distress.

There is no significant difference among parents of mentally retarded children on extrinsic religious orientation as far as their gender is concerned. However, significant difference was found among parents of mentally retarded children on intrinsic religious orientation and psychological distress with respect to their gender. Fathers were found high on intrinsic religious orientation as compared to the mothers. The earlier researches on intrinsic religious orientation among parents of mentally retarded children with respect to their gender have mixed results. Several studies are inconsistent with our findings. For example, Cirhinlioglu and Demir (2012) conducted a study to examine religious orientation and its relation to locus of control and depression and found that female participants had higher levels of intrinsic religiosity than male participants. Similarly, Beisinger and Arikawa (2008) in a study examined that there was no significant differences between fathers and mothers on their intrinsic orientation and extrinsic orientation.

As compared to fathers, mothers of mentally retarded children were found high on psychological distress. These finding are in consonance with the findings of Peshawaria, Menon, Ganguly, Roy, Rajan, \& Gupta (1998); Hedov, Anneren, and Wikblad 2000; and Seshadri, Verma, and Prashad (2000), indicating that women are more affected in coping with stresses of a child's intellectual disability. Mothers appear to be more vulnerable to psychological distress than fathers, which may be attributed to the fact that mothers are typically more involved with the day-to-day care of their children (Little, 2002; Murphy, Bruno, Abbeduto, Giles, Richmond, \& Orsmond, 2004). Similarly Blacher, Lopez, Shapiro, \& Fusco (1997) and White \& Hastings (2004) in their studies found that in response to heightened stress, mothers of children with mental retardation often demonstrate increased depression compared to mothers of children without mental retardation.

\section{REFERENCES}

Allport, G. W., \& Ross, J. M. (1967). Personal religious orientations and prejudice. Journal of Personality and Social Psychology, 5(4), 432-443.

American Psychiatric Association (2013). Diagnostic and statistical Manual of mental disorders $\left(5^{\text {th }}\right.$ ed., text rev.). Washington, DC: Author.

Baker, M., \& Gorsuch, R. (1982). Trait anxiety and intrinsic-extrinsic religiousness. Journal for the Scientific Study of Religion, 21, 119-122. 


\section{Religious Orientation and Psychological Distress among Parents of Mentally Retarded Children}

Barlow, D., \& Durand, V. (2005). Abnormal psychology: An integrative approach. Belmont, CA: Thomson Wadsworth.

Bergin, A. E., Masters, K. S., \& Richards, P. S. (1987). Religiousness and psychological wellbeing re-considered: a study of an intrinsically religious sample. Journal of Counseling Psychiatry, 34, 197-204.

Biesinger, R., \& Arikawa, R. (2008). Religious attitude and happiness among parents of children with developmental disabilities. Journal of Religion, Disability \& Health, 11(4), 23-34.

Blacher, J., Shapiro, J., Lopez, S., Diaz, L., \& Fusco, J. (1997). Depression in Latina mothers of children with mental retardation: A neglected concern. American Journal of Mental Retardation, 101(5), 483-496.

Breslau, N., \& Davis, G. C. (1986). Chronic stress and major depression. Archives of General Psychiatry, 43, 309-314.

Census (2011). Office of the Registrar and Census Commiosner, Ministry of Home Affairs, Govt. of India. Retrieved from: Website: http://www.censusindia.gov.in

Cirhinlioglu, F. G., \& Demir, G. O. (2012). Religious orientation and its relation to locus of control and depression. Archive for the Psychology of Religion, 34, 341-362

Cohen, D. S., Friedrich, W.N., \& Jaworski, T. M. (1994). Paediatric cancer: predicting sibling adjustment. Journal of Clinical Psychology, 50(3), 303-319.

Davis, T. L., Kerr, B. A., \& Kurpius, S. E. R. (2003). Meaning, purpose, and religiosity in at-risk youth: The relationship between anxiety and spirituality. Journal of Psychology and Theology, 31, 356-365.

Dyson, L. L. (1989). Adjustment of siblings of handicapped children: a comparison. Journal of Paediatric Psychology, 14(2), 215-229.

Flynt, S. W., Wood, T.A., \& Scott, R. L. (1992). Social support of mothers of children with mental retardation. Mental Retardation, 30(4), 233-236.

Gallimore, R., Weisner, T. S., Kaufman, S. Z., \& Bernheimer, L. P. (1989).The social construction of ecocultural niches: Family accommodation of developmentally delayed children. American Journal on Mental Retardation, 94(3), 216-230.

Genia, V. (1996). Intrinsic, Extrinsic, Quest, and fundamentalism as predictors of psychological and spiritual well-being. Journal for the Scientific Study of Religion, 35, 56-64.

Genia, V., \& Shaw, D. G. (1991). Religion, intrinsic-extrinsic orientation, and depression. Review of Religious Research, 32, 274-283.

Ghorbani, N., \& Watson, P. J. (2006). Religious orientation types in Iranian Muslims: Differences in alexithymia, emotional intelligence, self-consciousness, and psychological adjustment. Review of Religious Research, 47, 303-310.

Gibson, C. H. (1995). The process of empowerment in mothers of chronically ill children. Journal of Advanced Nursing, 21(6), 1201-1210.

Gorsuch, L. R., \& Venable, G. D. (1983). Development of an "Age Universal" I-E Scale. Journal for the Scientific Study of Religion, 22(2), 181-187. 


\section{Religious Orientation and Psychological Distress among Parents of Mentally Retarded Children}

Hackney, C. H., \& G. S. Sanders (2003). Religiosity and mental health: A meta-analysis of recent studies. Journal for the Scientific Study of Religion 42, 43-55.

Hamlett, K.W., Pellegrini, D. S., \& Katz, K. S. (1992). Childhood chronic illness as a family stressor. Journal of Paediatric Psychology, 17(1), 33-47.

Heaman, D. J. (1995). Perceived stressors and coping strategies of parents who have children with developmental disabilities: A comparison of mothers with fathers. Journal of Pediatric Nursing, 10 (5), 311-320.

Hedov, G., Anneren, G., and Wikblad, K. (2000). Self perceived health in Swedish parents of children with Downs syndrome. Quality of life research, 9(4), 415-422.

Hettler, T. R, \& Cohen, L. H. (1998). Intrinsic religiousness as a stress-moderator for adult protestant churchgoers. Journal of Community Psychology, 26, 597-609.

Jessop, D. J., Riessman, C. K., \& Stein, R. E. K. (1988). Chronic childhood illness and maternal. mental health. Journal of Developmental and Behavioural Paediatrics, 9, 147-156.

Kendler, K. S., Gardner, C. O., \& Prescott, C. A. (1997). Religion, psychopathology, and substance use and abuse: A multi-measure, genetic-epidemiologic study. American Journal of Psychiatry, 154, 322-329.

Kessler, R. C., Andrews, G., Colpe, L. J., Hiripi, E., Mroczek, D., Normand, L. T., . . . Zaslavsky, A. M. (2002). Short screening scales to monitor population prevalence and trends in non-specific psychological distress. Psychological Medicine, 32, 959-976.

Kessler, R. C. (1996). Kessler's 10 Psychological Distress Scale. Boston, MA: Harvard Medical School.

Koenig, H. G. (1995). Religion and older men in prison. International Journal of Geriatric Psychiatry, 10, 219-230.

Koenig, H. G., McCullough, M. E., \& Larson, D. B. (2001). Handbook of religion and health. New York: Oxford University Press.

Koller, H., Richardson, S. A., \& Katz, M. (1992). Families of children with mental retardation: comprehensive view from an epidemiologic perspective. American Journal on Mental Retardation, 97(3), 315-332.

Levin, J. S. (2001). God, Faith, and Health: Exploring the Spirituality-healing Connection. New York: John Wiley \& Sons.

Levin, J. S., \& Schiller, P. L. (1987). Is there a Religious Factor in Health? Journal of Religion and Health, 26(1), 9-36.

Levin, J. S., \& Chatters, L. M. (1998). Research on religion and mental health: An overview of empirical findings and theoretical issues. In H. G. Koenig (Ed.), Handbook of Religion and Mental Health (pp. 70-84). San Diego, CA: Academic Press.

Little, L. (2002). Differences in stress and coping for mothers and fathers of children with Asperger's syndrome and nonverbal learning disorders. Pediatric Nursing, 28, 565-570.

Maltby, J., \& Day, L. (1999). Depressive symptoms and religious orientation: Examining the relationship between religiosity and depression within the context of other correlates of depression. Personality and Individual Differences, 28, 383-393. 
Murphy, M., Bruno, L., Abbeduto, N., Giles, E., Richmond, \& Orsmond, G. (2004). Psychological well-being among parents of youth with Down syndrome or fragile $X$ syndrome. Poster session presented at the Academy on Mental Retardation Annual Meeting Program. Philadelphia, PA.

NSSO (2003). National Sample Survey Organization: A report on disabled persons. New Delhi: Department of Statistics (GOI).

Olson, M. M., Dollahite, D. C., \& White, M. B. (2002). Involved fathering of children with special Needs: Relationships and Religion as Resources. Journal of Religion, Disability \& Health, 6, 47-62.

Park, C., Cohen, L. H., \& Herb, L. (1990). Intrinsic religiousness and religious coping as life stress moderators for Catholics versus Protestants. Journal of Personality and Social Psychology, 59, 562-574.

Peshawaria, R., Menon, D. K., Ganguly, R., Roy, S., Rajan P., \& Gupta S. A. (1998). Study of Facilitators and Inhibitors that effect coping in parents of children with mental retardation in India. Asia Pacific Disability Rehabilitation Journal, 9(1), 118-126.

Seshadri, M. K., Verma, S. K., \& Prashad. (2000) Impact of mental retardation of child on the family in India. Journal of Clinical Psychology, 473-498.

Shumaker, J. F. (Ed.). (1992). Religion and Mental Health. New York: Oxford University Press.

Skinner, D. G., Correa, V., Skinner, M., \& Bailey, D. B. (2001). Role of religion in the lives of Latino families of young children with developmental delays. American Journal on Mental Retardation, 106, 297-313.

Thompson, R. J., Gil, K. M., Burbach, D. A., Keith, B. R., \& Kinney, T. R. (1993). The role of child and maternal processes in the psychological adjustment of children with sickle cell disease. Journal of Consulting and Clinical Psychology, 61, 468-474.

Ventis, W. L. (1995). The relationships between religion and mental health. Journal of Social Issue, 51, 33-48.

White, N., \& Hastings, R. P. (2004). Social and professional support for parents of adolescents with severe intellectual disabilities. Journal of Applied Research in Intellectual Disabilities, 171, 181-190.

World Health Organization (1989). World Health Organization Training in the community for people with disabilities. Geneva. 